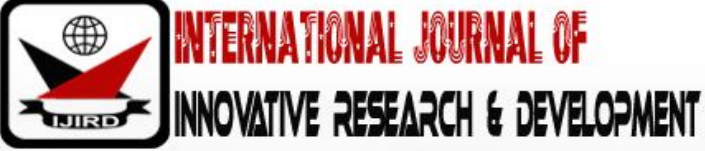

ISSN 2278 - 0211 (Online)

\section{Contribution of SOS Childrens Villages HIV/ Aids Project on Poverty Reduction of Vulnerable Families Living with Hiv/ Aids: Case Study of SOS Children's Village Kayonza, Rwanda}

Umuhoza Huguette
Student, Department of Development studies, Jomo Kenyatta university of Agriculture and
Technology, Kenya
Dr. Patrick Mulyungi
Lecturer, Department of Development studies, Jomo Kenyatta university of Agriculture and
Technology, Kenya

\begin{abstract}
:
The invention of Village microfinance or Village Savings and Loan Associations (VSLA) methodology of microfinance by CARE International changed the financial industry at a time when many people had no access to affordable financial services. This has had a lot of impact in the household level by improving their livelihoods, education access etc. However, many households are still facing with various sustainability challenges, which if not addressed could affect the life of the family members in the long-term. The purpose of the study was to examine the contribution of SOS children's villages HIV/ AIDS project on poverty reduction of vulnerable families living with HIV/ AIDS. Case study of SOS children's village Kayonza. The objectives of this study were: to establish the extent to which saving programs contributes to poverty reduction of vulnerable families living with HIV/ AIDS in Kayonza District, to investigate how business training contributes to poverty reduction of vulnerable families living with HIV/ AIDS in Kayonza District, to explore the extent to which group partnership contributes to poverty reduction of vulnerable families living with HIV/ AIDS in Kayonza District and to assess the level at which access to credit contributes to poverty reduction of vulnerable families living with HIV/AIDS in Kayonza District. Descriptive research design was used to collect quantitative data from a target population of 110 members of VSLAs from SOS in Rwanda. A sample size of 87 respondents, and 2 TOTs within SOS village in Kayonza. Data collection was done using questionnaires which were administered to the respondents who are members of the village saving and Loan Associations. Content validity was used to establish the appropriateness of the instruments while half-split method was used to establish reliability. Quantitative data from the field was processed using SPSS (Statistical Package for Social Sciences) Version 21. The analyzed data was presented in the form of tables using frequencies and percentages. The study found out that Saving programs, Business training, Group partnership and Access to credit to a constant zero, poverty reduction of vulnerable families living with HIV/ AIDS would be at 0.174. The study concluded that Economic empowerment has the potential to reduce the negative impact of AIDS on household economies through programs that foster savings and stimulate the development of Income-Generating Activities further The study recommendations to Government, NGO sectors and other stakeholders; the study implementation of HIV/ AIDS related projects and micro-finance projects that would support and improve on the women's income which is a source of their livelihood in the community. These programmes should focus on an attempt that would protect women's rights more so on property ownership and inheritance of assets. The study also recommended that women should be empowered to be economically empowered to decrease their vulnerability to HIV/ AIDS risky behaviors.
\end{abstract}

Keywords: Saving programs, business training, poverty reduction, vulnerable families, HIV/ AIDS, kayonza district

\section{Background}

The disease AIDS (Acquired Immuno Deficiency Syndrome) caused by Human Immuno Deficiency Virus (HIV) has been in existence since 1981, when the first instance was initially diagnosed. Globally by the end of 2009, around 33.3 million people were living with HIV virus (UKAID, 2010). Currently, it is estimated that 2.6 million people become infected with HIV virus and 1.8 million people die of AIDS every year (CARE, 2014). The combined effects of new HIV infections and the beneficial impact of antiretroviral therapy quantify the continuing rise in the population of people living with HIV. 
CARE (2009) estimated that around 2.2 million people were living with HIV in Europe at the end of 2009. According the report, adult HIV prevalence was estimated to vary below $0.1 \%$ in parts of Central Europe to above 1\% in parts of the former Soviet Union. In the United States, CDC (2009) statistics estimated that more than one million people were living with HIV in the United States, and more shockingly, one in five (21\%) of those people living with HIV is unaware of their infection. However, despite increases in the total number of people living with HIV in the US in recent years, the annual number of new HIV infections has remained relatively stable. Though, new infections continue at far too high a level, with an estimated 56,300 Americans becoming infected with HIV each year.

Sub-Saharan Africa remains the region most heavily affected and heterosexual exposure is the primary mode of transmission in sub-Saharan Africa. The region burdens 67 percent of HIV infections worldwide, 68 percent of new HIV infections among adults and 91 percent of new HIV infections among children. The region also accounted for 72 percent of the world's AIDS-related deaths in 2008 (UKAID, 2009).

HIV AIDS remains the leading cause of death among women of reproductive age. Right from the first decade of HIV AIDS pandemic, the WHO (World Health Organization) estimated that there were about 500,000 cases of AIDS in women and children. By the end of 2006, more than a half of the 60 million adults estimated to be leaving with HIV were women. 98 percent of who were women from developing countries (CARE, 2014). At the end of 2009 it was estimated that out of the 33.3 million adults worldwide living with HIV and AIDS, more than half are women (UNAIDS, 2009). It is suggested that 98 percent of these women live in developing countries. The AIDS epidemic has had a unique impact on women, which has been exacerbated by their role within society and their biological vulnerability to HIV infection (Carney, 2014). The percentage of women living with HTV and AIDS varies significantly between different regions of the world. In areas such as Western and Central Europe and Oceania, women account for relatively low percentage of HIV infected people. For example, In USA around 30 percent of people living with HIV AIDS are women, while 39.3 percent in India and 26 percent in Germany and United Kingdom. However, in regions such as sub-Saharan African and especially in Botswana and South African percentages are significantly higher than other regions (Allen, 2012).

In July 2009 UNAIDS announced that of all Africans aged 15-49 years who are HIV AIDS positive, women make up a disproportionate 57 percent of the population (UNAIDS, 2010). In Sub-Saharan African, women make about 60 percent of the total population living with HIV AIDS (UNAIDS 2009). The women and Girls in the Sub-Saharan Africa are especially vulnerable to HIV infections due to social, economic and political inequalities between women and men, which result in sexual violence and unequal access to prevention, education and training, and care. Girls and young women are less likely than boys and young men to understand key issues around HIV transmission and how to protect themselves. Violence against women is both a cause and a consequence of being infected with HIV. Women's lack of empowerment coupled with the social norms that accept violence against women and coercive sexual relations contribute to a more rapid spread of HIV (Opiyo, Yamano and Jayne 2009).). Biologically women are twice more likely to become infected with HIV through unprotected heterosexual intercourse than men (WHO, 2009). Additionally, millions of women have been indirectly affected by the HIV and AIDS epidemic. Women's childbearing role means that they have to contend with issues such as mother-to-child transmission of HIV. The responsibility of caring for AIDS patients and orphans is also an issue that has a greater effect on women (Nyangweso, 2010).

The AIDS pandemic has had adverse effects on social and economic development of women. In areas with few palliative care facilities, when a person becomes ill from AIDS the care is usually a woman's responsibility. For example, in Africa, two thirds of all caregivers for persons living with HIV and AIDS are women. This is in addition to many other tasks that women perform within the household, such as cooking, cleaning, and caring for the children and the elderly (Sidibe, 2009). Families affected by AIDS suffer from increasing poverty. Many families tap into their savings if available and taking on more debt are usually the first options chosen by households struggling to pay for medical treatment or funerals. Then as debts mount, precious assets such as bicycles, livestock and even land are sold. Once these households have been stripped of their productive assets, the chances of them recovering and rebuilding their livelihoods becomes slimmer. In many cases, the responses to a death in poorer households is removing the children especially girls from school (Sidibe, 2009). Nyangweso, (2010) Indicates that poverty has been found to be both a cause and effect of HIV AIDS pandemic among women. Women from poor backgrounds stand increased risk of contracting HIV mainly through channels of increasing high risk behaviors. In Zambia frequent droughts and limited wage job opportunities after the post-economic liberalization closure of companies were identified as the push factors for women increasingly resorting to transactional sex (Williams \& Wilkins, 2009). In South Africa, girls between the aged 14-22 years, first sexual debut is earlier in poor households. In Botswana and Swaziland, food insufficiency among women is significantly associated with inconsistent condom use with a non-primary partner, exchange of sex for resources, intergenerational sexual relationships and lack of control in sexual relationships. For men, food insufficiency was associated (Williams \& Wilkins, 2009). In response to reducing the burden of the HIV AIDS pandemic and causes of HIV AIDS among women multi-sectorial strategies and programmes that addresses poverty, gender inequalities and social marginalization must be supported as key components of a comprehensive AIDS strategy (USAID, 2009). The USAID report, (2009) indicates that research suggests that addressing women's basic economic needs through programs such as microfinance, youth livelihoods and life skills training, and initiatives to protect women's food security and property and inheritance rights not only targets women's economic vulnerability directly but can also offer a strategic opportunity for attracting sustained group-based participation in HIV prevention activities among the poor. Experience suggest that with combined economic empowerment and HIV interventions, it is feasible to address structural factors such as poverty, gender inequalities and gender-based violence as part of HIV prevention programs. Adequate resources, technical expertise, and monitoring and evaluation mechanisms relating to these goals need to be included to support effective HIV AIDS prevention programs (USAID, 2009). 
The main sources of income for poor people in East Africa are farming and trading produce, petty trade, casual employment, artisan work such as tailoring, welding, stone quarrying and brick making, local brewing and food vending. To secure a regular income, VSLA members are encouraged to invest in productive assets and income generating activities to diversify their income sources. More than $60 \%$ of VSLA members have two or more sources of income, which is a significant improvement compared to non-members who mainly depend on only one source. Likewise, VSLA members are able, to a greater extent than non-members, to acquire assets either to increase their household income directly or to enable them to access markets (for example, by means of a radio, mobile phones, and motorcycles). Since pre-colonial and after colonial, Rwanda efforts have been directed towards the poverty eradication, economic growth and development, through agriculture commercialization, tourism and industrialization. In relation to this and through the Private Sector Foundation the country has focused on sustainable development through small business development (RDB, 2014). Community's performance towards poverty eradication, has occupied a prominent place and the parties to the community especially women and youth must be part of this fight if economic hindrances of poverty are to be eradicated from societies because women are the back bone of the society. Thus, the recent poverty eradication program in Rwanda is focused on sustainable development through small business development, as the Government of Rwanda focus on much interest placed on the development of the private sector, being the pillar of poverty eradication at all levels in the society (RDB, 2014).

The Rwandan economy is based on the largely rain fed agricultural production of small, semi subsistence and increasingly fragmented farms with large involvement of women, the micro-credit projects spearheaded the Rwandan government is focused on the improvement of communities' livelihoods. This is to be achieved by contributing to effective poverty reduction and complimentary economic development activities for sustainable financial empowerment especially through small and medium businesses. Hence the overall objective is to provide a venue for income-generating activities, small and medium businesses through a rotating microfinance scheme which is aimed at creating and engaging rural community in income generating activities to foster their financial stability (MINICOM, 2010). It is upon the above background, that is why the researcher would like to examine the extent to which Village Saving and Loan Associations can have contributed to the improvement of living conditions of their members.

\subsection{Statement of the Problem}

It is observed that women especially widows and elderly grandmothers, bear the brunt of caring for People Living with HIV and AIDS (PLWHA). Further they are responsible for securing household food and income. However, these women face critical marginality in community resource access and information. This contributes to their challenges in access to credit which has been exacerbated by the loss of male relatives. Culturally the men have greater access to sources of financial support that had benefited the whole family. Family are at risk of HIV infection because of their economic vulnerability motivates their participation in commercial sexual practices. According to (Nyanweso, 2011), economic empowerment has the potential to reduce the negative impact of AIDS on household economies through programs that foster savings and stimulate the development of Income-Generating Activities (IGAs). This study called for strong and informative evaluations. In the past, evaluations of economic empowerments programs have tended to focus on measuring conventional financial indicators such as poverty targets or financial sustainability measures (USAID, 2008). However, broader impacts on dimensions on how saving, group partnerships, access to credit and business trainings influence women HIV AIDS risk behavior change not been established. USAID, (2008) report is in agreement with this, the report indicates that less has been done to establish the link of economic empowerment with HIV prevention goal. By providing a detailed exploration of how vehicles such as SOS children villages or livelihoods initiatives might impact on a range of HIVrelated outcomes among families in Kayonza District. This study therefore aimed at aimed examine the contribution of SOS children's villages HIV/ AIDS project on poverty reduction of vulnerable families living with HIV/ AIDS. Case study of SOS children's village Kayonza.

\subsection{Objectives of the Study}

\subsubsection{General Objective}

The general objective of this study was to examine the contribution of SOS children's villages HIV/ AIDS project on poverty reduction of vulnerable families living with HIV/ AIDS. Case study of SOS children's village Kayonza.

\subsubsection{Specific Objectives}

The following specific objectives guided the study:

- To establish the extent to which saving programs contributes to poverty reduction of vulnerable families living with HIV/ AIDS in Kayonza District. 
2. Conceptual Framework

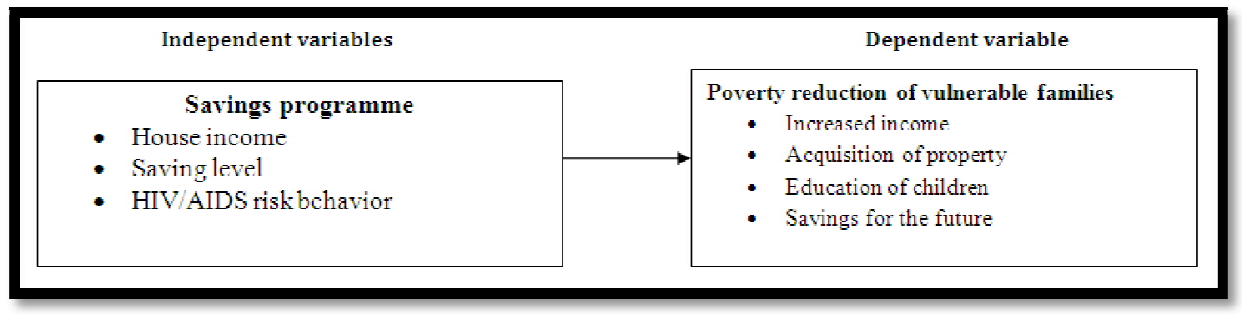

Figure 1: Conceptual Framework

\section{Target population}

The study targeted a population of 110 individuals. This comprised 100 family members from Kayonza District, one Project manager, two project officers, two field officer and 5 CBTs. The 20 groups were trained by five communitybased trainers in four locations. Each group has five officials; chairperson, secretary, treasurer and two money counters. This is the population from which the sample was drawn. A target population should have observable characteristics from which the researcher intends to generalize the findings of the study (Gray, 2014).

\begin{tabular}{|c|c|}
\hline Area of Operation & Population \\
\hline VSL family members & 100 \\
\hline Project manager & 1 \\
\hline Project officer & 2 \\
\hline Field officer & 2 \\
\hline CBT & 5 \\
\hline Total & 110 \\
\hline
\end{tabular}

Table 1: Sampling Frame

\section{Research Findings and Discussion}

\subsection{Saving Programs and Poverty Reduction}

The study sought to establish the influence of Saving Programmes on poverty reduction in Kayonza District. The specific parameters for analysis were; whether they were involved in saving programme, has the level of savings increased, sources of savings, sources of income, and level of income. To measure the HIV/ AIDS risk, the respondents were asked whether there were respondents within the group whom were having multiple sexual partners for economic gain

The provision of savings accounts, loans to poor women and men through microfinance initiatives has greatly benefited those who are not served by formal banking systems. Cultural barriers, lack of access to education and. limited property titles and inheritance rights, low status of women, illiteracy, often prevent poor people from obtaining finance from banks. Landless women are particularly excluded from formal financial services due to the lack of collateral. The use of financial services helps poor respondents increase and diversify incomes, build human, social and economic assets, and improve their livelihoods. Increased access to safe places to save also provides vulnerable women with improved security against crises, such as HIV/ AIDS.

\begin{tabular}{|c|c|c|c|}
\hline & & Frequency & Percent \\
\hline Valid & Yes & 37 & 46.3 \\
\cline { 2 - 4 } & No & 11 & 13.8 \\
\cline { 2 - 4 } & Not Sure & 32 & 40.0 \\
\cline { 2 - 4 } & Total & 80 & 100.0 \\
\hline
\end{tabular}

Table 2: Multiple Partners for Economic Gain

Source: Primary Data, 2019

From the findings, majority 37 (46.3\%) indicated that there were group members going out with multiple sexual partners for economic gain. 11 (13.8\%) indicated no knowledge, while 80(31.4) said they were not sure. This implied that majority of the respondents engaged multiple sexual partners as a way of earning extra income. This increased the vulnerability of the respondents to HIV because this furthers their dependence on men and constrains their ability to negotiate for safe sex. These findings are in line with those Kima (2015) who did a study in Botswana and found that women earn 30- 40\% less than men for the same work, and most of those who are working are employed outside the formal sector in jobs characterized by income insecurity and poor working conditions. She urged that this economic vulnerability increases their vulnerability to HIV by furthering their dependence on men and constraining their ability to refuse sex, negotiate the use of a condom, discuss fidelity with their partners, or leave risky relationships. 
4.1.1. Influence of Engaging In a Saving Program on the Risk of Contracting HIV/ AIDS among Members in Kayonza District

Saving programs encourage self-sufficiency, financial management and asset accumulation. Saving programs are strategies of economic empowerment. Therefore, the study sought to find out how many of the respondents were involved in the saving programs.

\begin{tabular}{|c|c|c|c|}
\hline & & Frequency & Percent \\
\hline \multirow{3}{*}{ Valid } & Yes & 66 & 82.5 \\
\cline { 2 - 4 } & No & 14 & 17.5 \\
\cline { 2 - 4 } & Total & 80 & 100.0 \\
\hline
\end{tabular}

Table 3: Involvement in Saving Programs

Source: Primary Data, 2019

From the Table 3 the study found out that majority of the respondents $66(82.5 \%)$ were involved in saving programs while $14(17.5 \%)$ of the respondents did not engage in any saving program. This implies that most respondents engage in a saving program in order to empower themselves economically.

\subsubsection{Respondents Preferred Scheme}

Village banking and self-help micro-finance group has been major methodologies used by numerous VSLA in fostering micro-finance among respondents. The study also sought to establish this factor.

\begin{tabular}{|c|c|c|c|c|c|c|}
\hline & \multicolumn{2}{|c|}{ Bank } & \multicolumn{2}{c|}{ Merry-g-round } & \multicolumn{2}{c|}{ Table banking } \\
\hline Response & Frequency & Percent & Frequency & Percent & Frequency & Percent \\
\hline Yes & 44 & 55.0 & 66 & 82.5 & 62 & 77.5 \\
\hline No & 36 & 45.0 & 14 & 17.5 & 18 & 22.5 \\
\hline Total & 80 & 100.0 & 80 & 100.0 & 80 & 100.0 \\
\hline
\end{tabular}

Table 4: Preferred Saving Scheme

Table 4 showed that majority of the respondents preferred saving through merrygo-round 66 (52.5\%) followed by table banking $62(77.5 \%)$ while only $44(55 \%)$ prefer saving through commercial banks. The study therefore concluded majority of the poor respondents in micro-economic empowerment program only access group savings schemes like the merry-go-round and table banking. These findings were supported by those of Mayoux (2018) argues that group-based programs are assumed to build or reproduce social capital through developing economic and social networks of marginalized people. This is then assumed to further empower the marginalized through enhancing their ability to increase incomes, negotiate change in the household and participate in collective social and political activities.

\subsubsection{Sources and Level of Income}

After establishing the preferred saving scheme, the study also sought to establish the sources and level of savings. Available literature indicates lacks of financial stability increases respondents' risk of contracting HIV/ AIDS. The findings were tabulated in Table 5 below

\begin{tabular}{|c|c|c|c|}
\hline \multicolumn{2}{|c|}{} & Frequency & Percent \\
\hline \multirow{3}{*}{ Valid } & Regular employment & 43 & 53.8 \\
\cline { 2 - 4 } & Income generating activity & 28 & 35.0 \\
\cline { 2 - 4 } & Donations from friends and well-wishers & 9 & 11.3 \\
\cline { 2 - 4 } & Total & 80 & 100.0 \\
\hline
\end{tabular}

Table 5: Respondents Sources and Level of Income

Source: Primary Data, 2019

When the respondents were asked to establish the sources and level of savings, majority 43 (53.8\%) said that they got their income through regular employment, 28 (35\%) said that they got their income through income generating activity while $9(11.3 \%)$ said that they got their income through Donations from friends and well-wishers. The study therefore concluded that despite the availability of savings scheme, these respondents' level of income was low while the level of their expenditures was high causing their saving levels to be very minimal. This implied that majority of these respondents were still economically vulnerable. These findings concurred with those of Pronyk, (2018) who argued that material poverty increased the risk of contracting HIV mainly through the channel of increasing high-risk behaviors' particularly for women.

\subsubsection{Respondents Level of Income}

Families' income improves the livelihood of the family and enables the family to buy the required basic necessities like foods, clothing and shelter among others. However, some families do not get enough income to be able to cater for its family mores of the respondents, HIV affected and infected families who need additional support. Therefore, the study sought to determine the levels of families' income. The findings are tabulated in the Table 6. 


\begin{tabular}{|c|c|c|}
\hline Amount Saved & Frequency & Percent \\
\hline$<10000$ & 30 & 37.5 \\
\hline $10000-20000$ & 19 & 23.8 \\
\hline $20001-30000$ & 12 & 15.0 \\
\hline $30001-40000$ & 19 & 23.8 \\
\hline $40001-50000$ & 0 & 0 \\
\hline$>50000$ & 0 & 0 \\
\hline Total & 80 & 100.0 \\
\hline
\end{tabular}

Table 6: Preferred Amount Saved by the Respondent

Source: Primary Data, 2019

Table 6 showed that majority of respondents 30 (37.5\%) had income levels less than Rwf 10000 followed by 19 (23.8\%) who indicated income levels of Rwf 10000 -20000. However very few 12 (15.0\%) had income levels between Rwf 20001 -30000. The study could therefore conclude that most of respondents in economic empowerment were poor respondents who lived on Rwf 30000 and below. These findings were in line with those of Julia Kim, (2015) who indicated that by improving access to credit and savings services, microfinance initiatives seek to provide business skills and income generating opportunities for poor women who are excluded from formal financial services and markets and this may reduce their chances of engaging in HIV/ AIDS risky behaviors for commercial gain.

\subsubsection{Model Summary}

Regression analysis was done to determine the relationship between SOS children's villages HIV/ AIDS project and poverty reduction of vulnerable families living with HIV/ AIDS. Case study of SOS children's village Kayonza.

\begin{tabular}{|c|c|c|c|c|}
\hline Model & R & R Square & Adjusted R Square & Std. Error of the Estimate \\
\hline 1 & $.934^{\mathrm{a}}$ & .889 & .881 & .727 \\
\hline
\end{tabular}

Table 7: Model summary

Predictors: (Constant), Saving programs, Business training, Group partnership and Access to credit Source: Primary data, 2019

According to Table 7, $\mathrm{R}=0.934$, this indicates that there is a strong relationship between SOS children's villages HIV/ AIDS project and poverty reduction of vulnerable families living with HIV/ AIDS. While R - square $=0.889$, this indicates that $88.9 \%$ variation in poverty reduction is explained by all the SOS children's villages HIV/ AIDS project (Saving programs, Business training, Group partnership and Access to credit) while the remaining $11.1 \%$ is explained by other factors.

\subsubsection{ANOVA}

To determine the level of significant ANOVA test was done on SOS children's villages HIV/ AIDS project and poverty reduction of vulnerable families living with HIV/ AIDS.

\begin{tabular}{|c|c|c|c|c|c|c|}
\hline \multicolumn{2}{|c|}{ Model } & Sum of Squares & Df & Mean Square & F & Sig. \\
\hline \multirow{3}{*}{1} & Regression & 5.548 & 4 & 5.548 & 19.999 & $.000^{\mathrm{a}}$ \\
\cline { 2 - 7 } & Residual & 9.709 & 35 & .277 & & \\
\cline { 2 - 7 } & Total & 15.257 & 39 & & & \\
\hline
\end{tabular}

Table 8: ANOVA Results Showing the Combined Effect Anovab

a. Dependent Variable: Poverty Reduction

b Predictors: (Constant), Saving Programs, Business Training, Group Partnership And Access To Credit

Source: Primary Data, 2019

The ANOVA test in Table 8 indicates that the significance of the P value 0.000 is less than 0.05 , VSLA activities are significant on poverty reduction of vulnerable families living with HIV/ AIDS. It is concluded that there is a significant effect of all the four-village SOS children's villages HIV/ AIDS project on poverty reduction of vulnerable families living with HIV/ AIDS.

\subsubsection{Overall Regression Model Coefficients}

Overall coefficients were done on the four variables of village savings and loan associations on sustainable livelihood in Rwanda. 


\begin{tabular}{|c|c|c|c|c|c|c|}
\hline Model & & \multicolumn{2}{|c|}{$\begin{array}{c}\text { Unstandardized } \\
\text { Coefficients }\end{array}$} & $\begin{array}{c}\text { Standardized } \\
\text { Coefficients }\end{array}$ & t & Sig. \\
\hline & & $\mathbf{B}$ & $\begin{array}{c}\text { Std. } \\
\text { Error }\end{array}$ & Beta & & \\
\hline 1 & (Constant) & 0.174 & .060 & & & .006 \\
\hline & Saving programs & 0.162 & .046 & .444 & 3.954 & .009 \\
\hline & Business training & 0.285 & .050 & 1.231 & 4.656 & .000 \\
\hline & Access to credit & 0.149 & .052 & 1.075 & 2.956 & .003 \\
\hline & Trainings & 0.219 & .044 & .230 & 3.184 & .000 \\
\hline
\end{tabular}

Table 9: Coefficient Results

From The Data In The Above Table The Established Regression Equation Was

$$
\mathrm{Y}=0.174+0.162 \mathrm{X} 1+0.285 \mathrm{X} 2+0.149 \mathrm{X} 3+0.219 \mathrm{X} 4
$$

From the above regression equation, it was revealed that Saving programs, Business training, Group partnership and Access to credit to a constant zero, poverty reduction of vulnerable families living with HIV/ AIDS would be at 0.174.

\section{Conclusions}

From the study data on influence of saving programme on poverty reduction of vulnerable families living with HIV/ AIDS, the extend of the influence was not established as majority of the respondents indicated that there aware of group members who were still having multiple partners for economic gain. However, from the findings, majority saved through the micro-finance-initiated schemes like Merry-go-round and Table banking. The findings also established that majority of the respondents had been economically empowered as most of the respondents indicated that their interests had increased. The study also indicated that majority of the respondents acquired their income through the IGAs. In addition, a cross tabulation of income versus HIV/ AIDS risk, majority within low income brackets were indicated to be more at risk of contracting HIV/ AIDS.

\subsection{Recommendations}

Through the saving programmes households' income increased and there was also increase in saving levels. However, majority of the respondents were still reported to be at risk. The study indicated that majority of the family's incomes had increased due to establishment of IGAs. The study also revealed that majority of those at risk was those within the low-income bracket.

\subsection{Areas for Further Research}

The study made the following suggestions for further research:

- The influence of economic empowerment strategy to other family household HIV/ AIDs risk behavior change.

- Other strategies that can influence respondents HI/AIDS risk behavior change apart from four identified strategies: the government motivated strategies, civil society, community-based organizations and self-motivated strategies.

\section{References}

i. Ahmed SM., (2015) Intimate partner violence against women: experiences from a woman-focused development programme in Matlab, Bangladesh. / Health Popul Nutr 2015; 23:95-101.

ii. Allen, H. (2012). Care International's VSL program in Africa, Microfinance for the Rural poor that work. Care International.

iii. Ainsworth, M. and Over, M. (2009): Confronting AIDS Public priorities in a global epidemic.

iv. World Bank Policy Research Report Washington, D.C., Oxford University Press,

v. Arvidsson A. (2006): Female Entrepreneurs in Microfinance -A Field Study to Serbia and

vi. Montenegro, University essay from Lunds University

vii. Babalola S, Tambashe BO, Vondrasek C. (2015) Parental factors and sexual risk-taking among

viii. $\quad$ young people in Cote d'lvoire. African Journal of Reproductive Health. 1):49-65.

ix. Buve A, Carael M, Hayes RJ, Auvert B, Ferry B and Robinson NJ, (2011): Multicentre study on factors determining differences in rate of spread of HIV in sub-Saharan Africa: methods and prevalence of HIV infection. AIDS.;15(suppl 4): S5-S14.

x. Carney, D. (2009) Approaches to Sustainable Livelihoods for the Rural Poor Overseas Development Institute.

xi. CARE. (2014).An initiative supporting the Basic Income and Needs Of HIV/ AIDS Affected Households and Individuals.

xii. CARE. (2014).CARE Training Course on IGA Selection, Planning, and Management.

xiii. CARE International in Rwanda (2009). "Village Savings and Loans and Women's Empowerment. "Strategic Impact Inquiry.

xiv. Cheston S, Kuhn L. (2012) Empowering women through microfinance. In: Harris SD, ed.

xv. Pathways out of poverty: innovations in microfinance for the poorest families. Bloomfield: CT: Kumarian Press, 2002:167-228.

xvi. Cooper, P. R. \& Schindler, P.S. (2011). Business research methods. New York: Wiley.

xvii. Gray, D. (2014) Doing Research in the Real World: London, Sage Publications 
xviii. Hulme D, (2005): Impact assessment methodologies for microfinance: theory, experience and

xix. better practice, Institute for Development Policy and Management University of Manchester, United Kingdom

xx. Hussey, R (2010). Review of the book Qualitative Methods in Business Research, A practical guide. Chicago: ALA

xxi. Jorgensen L. N. J., (2009): Revisiting social capital in development: can group-based microfinance reproduce social capital? A case study in rural Cambodia

xxii. Kima J., (2009): Exploring the role of economic empowerment in HIV prevention

xxiii. Kirubi M, Ngugi EN, Kamau P, Nyanbola L, Ronald A. (2014) The impact of social, economic and sexual empowerment: commercial sex workers [abstract 447D].Xinternational conference on AIDS, Yokohama

xxiv. Kombo, D.K., \& Tromp, D.L.A. (2009). Proposal and thesis writing: An introduction.

xxv. Nairobi. Pauline's Publications Arica.

xxvi. Kothari, C. (2014). Research methodology: Methods and Techniques. (3 ${ }^{\text {rd }}$ ed.). New

xxvii. Delhi: New Age International.

xxviii. $\quad$ Luiangadura B. G., (2015): Gender, HIV/ AIDS and rural livelihoods in southern Africa:

xxix. addressing the challenges, Journal of Culture and African Women Studies @ ISSN: 1530- 5686Issue

xxx. Mugenda, O. M., \& Mugenda, A. G. (2008). Research methods: Quantitative and qualitative approaches. NairobiKenya: Acts Press.

xxxi. $\quad$ Mugenda, O.M., \& Mugenda, A.G. (2013). Research methods. Nairobi: McMillan Publishers.

xxxii. Morduch, J. (2012), "The Micro Finance Promise", Journal of economic Literature, Vol. 37, No. 4 pp. 1569-1614.

xxxiii. NACADA, (2014), Youth in Peril: Alcohol and Drug Abuse in Kenya. National Agency for the Campaign Against Drug Abuse; Nairobi.

xxxiv. Nawal, M (2016): Health Consequences of Child Marriage in Africa, CDC Hour. Vol. 12

xxxv. N'gugi, R. (2009). "Health Seeking Behavior in the Reform Process for Rural Households;

xxxvi. The case of Kenya rural homes." AERC Research paper No. 5.

xxxvii. Nlayoux L., (2009). Women's empowerment and micro-finance: programmes, approaches, evidence, and ways forward. Milton Keynes: Open University, 2008. (Development policy and practice working paper 41.)

xxxviii. Nsutebu, E.F., John D. Walley., Elizabeth Mataka., Chanda Fikansa Simon. (2011). "Scaling-up HIV/ AIDS and TB Home-Care: Lessons from Zambia."

xxxix. Odhiambo. C. (2012). HIV/ AIDS and Women in Africa. International Journal of Humanities and Social Science 2:2: Special Issue.

xl. Opiyo PA, Yamano T, and Jayne TS. (2009). HIV/ AIDS and home-based health care. International Journal for Equity in Health 7 (8).

xli. Orodho, A.J. (2013). Essentials of educational and social science research method. Nairobi: Masola Publishers.

xlii. Philipson, T. and Posner, R. (2015): "The Microeconomics of the ALDS Epidemic in Africa" Vol. 21: pp. 835-848

xliii. Pronyk PM, Kim JC, Hargreaves JR, Makhubele MB, Morison LA, Watts CH, (2012)

xliv. Microfinance and HIV prevention: perspectives and emerging lessons from rural South Africa.

xlv. Rwanda, C. (2009).CKWASEH End term Evaluation Report. .

xlvi. Rwanda Development Board RDB, (2014)World Development Report 2014/2015: Attacking Poverty'. New World Bank Group'sMicro Finance Institutional Action Plan 2014

xlvii. Sachs J. (2015). The end of poverty: How we can make it happen in our lifetime. London:

xlviii. Penguin

xlix. Saunders, M., Lewis, P., \& Thornhill, A. (2009). Research methods for business students.

1. (5th Ed.). London: Prentice Hall.

li. Schreiner M., (2013), Microenterprise Development Programs in the United States and in the Developing World Washington University in Saint Louis, MO, USA

lii. Seibel H. D., \& Almeyda G., (2016): Women and men in rural microfinance: the case of

liii. Uganda Development Research Center, University of Cologne

liv. Siddique I. Q., (2010): Case Study on a Slum Improvement Project, Dhaka Metropolitan City Steele F., Amin S., and Naved T. R., (2009): Paper on The Impact of an Integrated Micro-

lv. credit Program on Women's Empowerment and Fertility Behavior in Rural Bangladesh

lvi. UKaid (2010). Working with Co-operatives for Poverty Reduction. Briefing note. Department for International Development.

lvii. UNAIDS (2011). Information note on effectiveness of condoms in preventing sexually transmitted infections including HIV. Geneva: WHO and UNAIDS; 2010.

lviii. UNAIDS (2009). Report on the Global AIDS Epidemic. Geneva: Arlington

lix. UNAIDS (2012) Senegal: A Success Story of AIDS Investment and Impact

lx. UNAIDS. (2010). Global Report: UNAIDS Report on the global Aids Epidemic 2010. United Nations: Geneva.

lxi. UNAIDS (2009). Joint United Nations Programme on HIV/ AIDS. The HIV/ AIDS situation in mid-2008: global and regional highlights. UNAIDS Fact Sheet. July 1,2008.

lxii. USAID region report. (2010). Economic deprivation of African women; Geneva: USAID; 2010.

lxiii. World Health Organization. (2009). New HIV recommendations to improve health, reduce infections and save lives. Geneva: World Health Organization.

lxiv. Zikmund, G.W., Babin, B.J., Carr, C.J., \& Griffin, M. (2010). Business research methods. (8th ed.). South-Western, Cengage Learning. 